Emission control
$\begin{aligned} & \text { Carbon-trading fund } \\ & \text { set to benefit world's } \\ & \text { poorest nations } \\ & p 4\end{aligned}$

\title{
US biologists wary of move to view embryos as human beings
}

\section{Erika Check, Washington}

An air of unease has settled over US researchers who work on human embryos, following a significant shift in the remit of a committee that advises on research involving human subjects.

For the first time, the advisory committee is being asked to broaden its scope to consider the welfare of embryos and fetuses involved in research.

Some scientists suspect that the move is a step towards extending the legal protection given to human embryos and fetuses. Should such a revision win approval, it could hamper some kinds of research, such as work on embryonic stem cells.

The charter for the new Secretary's Advisory Committee on Human Research Protections, details of which were revealed in The Washington Post on 30 October, instructs its members to pay particular attention to "pregnant women, embryos and fetuses", among other groups. The panel was set up last month, although its members have yet to be appointed. It is the successor to the National Human Research Protections Advisory Committee, set under the Clinton administration, which was not asked to consider the welfare of embryos or fetuses.

The committee is appointed by the Department of Health and Human Services (HHS), and does not have the power to make new rules. Instead, its recommendations must be passed into law by Congress or made into policy by HHS officials.

But many observers suspect that the Bush administration will use decisions made by the committee to back up the case for greater legal protection of embryos and fetuses. They are worried, for example, that health secretary Tommy Thompson may appoint committee members who support such changes to the law.

Stem-cell researcher Irving Weissman of Stanford University in California echoes these concerns. "I am very nervous that political activity at the input decides the outcome, and this administration may be

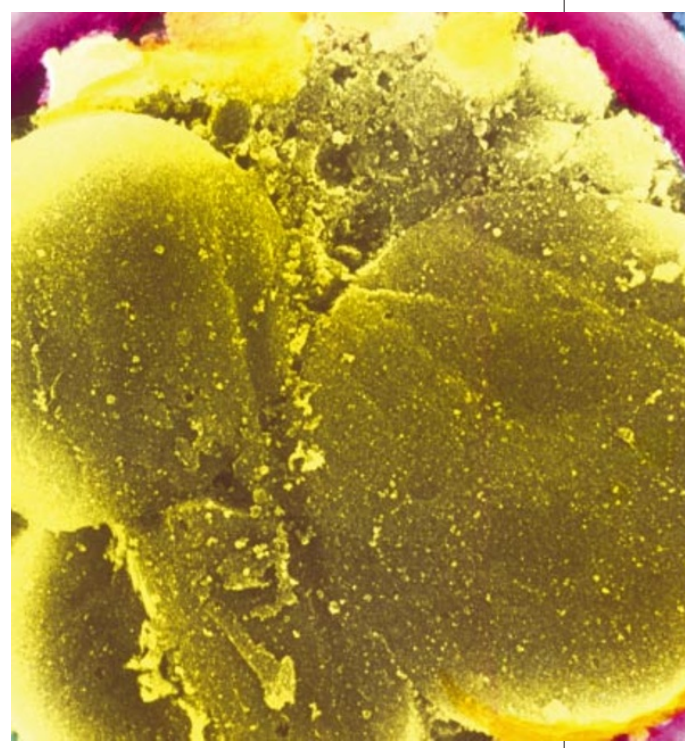

Ball of confusion: is an embryo a collection of cells or should it have the same rights as an adult?

\section{Gene centre chips in with better route to microarrays}

Alison Abbott, Munich

Biologists who make their own DNA microarrays, rather than relying on expensive commercial chips, should now be able to do a better do-it-yourself job, thanks to a set of human DNA clones made available by the German Genome Resource Centre (RZPD) in Berlin.

Microarrays are increasingly being used by researchers interested in gene expression, allowing them to compare the activity of thousands of genes in, for example, cancerous and non-cancerous tissues. Most commercial systems consist of arrays of thousands of short nucleotide synthetic sequences, called oligonucleotides, designed to bind to specific messenger RNAs (mRNAs), which are transcribed from active genes.

But many researchers opt instead to make their own cheaper microarrays from complementary DNAs (cDNAs), which are made from mRNAs directly, using a reverse transcriptase enzyme. Each cDNA binds to the same mRNA from which it was created. Once a researcher has obtained a library of cDNAs, they can make copies of the cDNAs to create many microarrays.

The non-profit RZPD says that its human cDNA clone set is of much higher quality than those produced by other labs, and is also better catalogued. The RZPD's first customers say that they can use the cDNA clones to create their own microarrays at a fraction of the cost of commercial oligonucleotide arrays.

The RZPD set has several advantages over other libraries. Each clone has been resequenced and verified as corresponding to its database sequence. About $10-20 \%$ of samples in most other cDNA libraries are incorrectly labelled. The RZPD has also gone to great lengths to be as sure as possible that each cDNA represents a unique gene, whereas most cDNA libraries contain multiple copies of mRNAs of particularly active genes.

"The availability of a sequence-verified, non-redundant cDNA library is fantastic global approaches to biological research hinge on the availability of high-quality reagents," says Steven Gullans, co-director of the Gene Array Center at the Brigham and Women's Hospital in Boston.

The RZPD clone set contains 32,000 genes, and a further 10,000 will be added over the next few months - giving it more genes than other libraries. "Spotting 40,000 or so cDNAs onto a microarray means that we can cover a large part of the human genome," says Jobst Landgrebe, a biochemist at the University of Göttingen. He adds that it will cost him no more than 75 euros (US\$75) to make a microarray from the cDNA set. www.rzpd.de 
going down that path," he says.

If the committee recommends that embryos should be afforded the same legal protection as adults, for example, researchers might not be able to use them in research that does not benefit the embryos. This could prevent researchers from using embryos left over from in vitro fertilization as sources of human embryonic stem cells.

Such a move would have implications for federally funded biomedical research, as the HHS has jurisdiction over the National Institutes of Health. It also oversees the Food and Drug Administration (FDA), and so can influence companies hoping to use research results to gain FDA approval for new drugs and therapies.

HHS spokesman Bill Hall denies that the change to the committee's remit is a political move, saying that it is directed at women who participate in studies, and not at scientists who do basic research. "It is incumbent on researchers to fully inform women who might be pregnant or might be planning to become pregnant about the risks of whatever study they're thinking about participating in," Hall says.

But some observers say that no matter what the intentions behind the change are, the move is still alarming for scientists and many other groups, such as those who wish to keep abortion legal. "It's a dangerous precedent to characterize a cluster of cells as a human subject," says Kevin Wilson, director of public policy for the American Society for Cell Biology.

\section{Developing countries to gain from carbon-trading fund}

\section{Natasha McDowell}

Rural communities in the world's poorest nations will be able to earn income by using their forests and agricultural land to sequester carbon dioxide, under a plan announced this week by the World Bank.

The BioCarbon Fund, launched on 5 November, will allow companies and publicsector organizations in the developed world to offset some of their carbon emissions by investing in projects in the developing world, such as tree-planting schemes, which absorb carbon from the atmosphere. Investors will earn credits that can be used to meet regulatory requirements or voluntary pledges to cut greenhouse-gas emissions.

The World Bank, which has set a target of US\$100 million for the fund, will control how the money is spent. It says that the fund will be supported by the private and public sectors. Fourteen businesses, ranging from power utilities to insurance companies, have already indicated an interest.

Ian Noble, a World Bank official who is chief adviser to the fund, says that investment will be made according to three criteria: cutting greenhouse-gas emissions, benefiting the environment by promoting biodiversity, and reducing poverty by encouraging sustainable development. One project already submitted for consideration involves planting a buffer of native trees around a Ugandan conservation area that has been encroached upon by local people. Locals will also be able

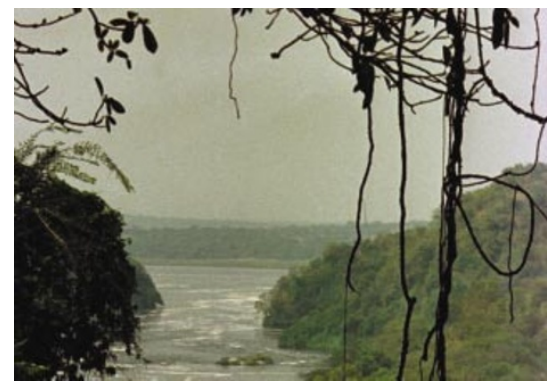

The White Nile flowing through Uganda, one of the nations that may benefit from the new plan.

to collect non-timber products from this buffer area.

Action groups have long advocated the use of carbon trading for social benefits. Last month, for example, the Centre for International Forestry Research in Bogor, Indonesia, and Forest Trends, a think-tank based in Washington DC, released a report showing that small-scale forestry projects integrated with rural agriculture can provide a cheap and comparatively low-risk way for poorer nations to generate carbon credits.

The BioCarbon Fund has earned further praise by including projects that are not covered by the Kyoto Protocol, the international agreement on limiting greenhousegas emissions. Conserving or restoring existing forest cannot be used to earn credits under the protocol, for example. But such projects will be covered by the new fund.

\section{Academies back Smithsonian's calls for direct funds}

\section{Kendall Powell, Washington}

Smithsonian Institution researchers breathed a collective sigh of relief last week, although their troubles may be far from over. Two reports released on 31 October state that the institution provides world-class science, and should continue to receive federal funding. But the future structure and funding of the Smithsonian depend on the outcome of a third report, expected in January.

The institution's research centres have been under a cloud for two years. Critics, including the White House Office of Management and Budget, suggested that Smithsonian scientists should compete for their funding rather than get it directly from government. Two of the centres were also threatened with closure, and a major reorganization seemed likely.

But last week's reports from the National Research Council, which is part of the
National Academies, and the independent National Academy of Public Administration (NAPA), will help to lift the gloom. The studies, which were commissioned by the Office of Management and Budget, say that removing direct funding could harm or even end top-notch research programmes.

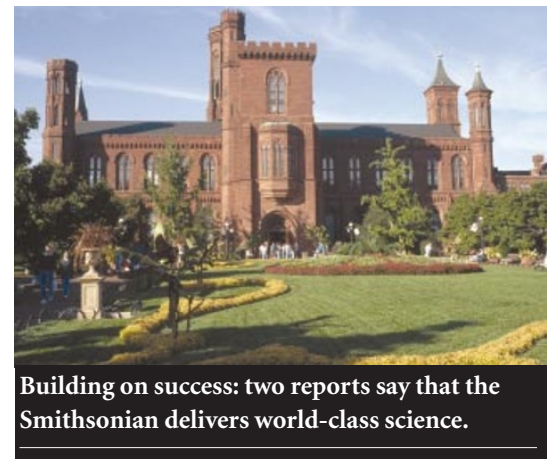

"It's a great thing to have outside organizations recognize the contributions we make," says Paula DePriest, associate botany curator at the Smithsonian's National Museum of Natural History in Washington DC. "We're going to see an increase in the morale of scientists here."

According to the reports, the federal funding — \$111 million in 2002 - supports core functions such as researcher salaries and facility maintenance. Competitive grants and contracts already support the main thrust of research projects, and totalled $\$ 98$ million in 2001, according to the NAPA study.

The Smithsonian's researchers are hopeful that the reports will bolster their cause, but they still face an anxious wait. The institution's own Science Commission, which it set up to advise it on setting research priorities for the future, will deliver its final report in early January. 